\title{
Phlebotomine Sand Flies in the State of Piauí, Brazil (Diptera: Psychodidae: Phlebotominae)
}

\author{
José Dilermando Andrade Filho/ ${ }^{+}$, Antônio Carlos Lima da Silva*, \\ Alda Lima Falcão
}

\author{
Laboratório de Leishmanioses, Centro de Pesquisas René Rachou-Fiocruz, Av. Augusto de Lima 1715, 30190-002 \\ Belo Horizonte, MG, Brasil *Fundação Nacional de Saúde, Coordenação Regional do Piauí, Núcleo de \\ Entomologia, Teresina, PI, Brasil
}

\begin{abstract}
In 1997, 1998 and 1999 we performed several captures in the State of Piaui, in the counties of Barro Duro, Campo Maior, Castelo, Floriano, Picos, São Raimundo Nonato and Teresina. We used CDC light traps inside houses, in a primary forest and in one cave. Seventeen species were collected being Lutzomyia longipalpis, Lutzomyia samueli, Lutzomyia whitmani and Lutzomyia lenti the most captured species. The genus Brumptomyia, L. whitmani, Lutzomyia sordellii, Lutzomyia carmelinoi, Lutzomyia termitophila, Lutzomyia peresi and Lutzomyia quinquefer are reported for first time in Piauí. We call the attention for the presence of L. whitmani and L. longipalpis, important vectors of leishmaniasis in various regions of South America.
\end{abstract}

Key words: Plebotominae - sand fly - Lutzomyia - Piauí - Brazil

Phlebotomine sand flies are originally found in forests, but due to the large devastation along the Brazilian forests, sand flies became adapted and may be found in modified rural and urban areas. Consequently a large number of cases of leishmaniasis can be observed in those areas and the disease became a health problem and endemic in several states of Brazil.

The State of Piauí has an absolute area of $252,378,6 \mathrm{~km}^{2}$ and population of 2,673,085 inhabitants, distributed among 221 municipalities (IBGE on line). Since the last decade several cases of visceral leishmaniasis were notified in the State, with a high concentration in the urban area of the Capital, Teresina (Costa et al. 1990, Costa 1993).

The fauna of sand flies in Piauí is poorly known. The vector of visceral leishmaniasis, Lutzomyia longipalpis has been captured in some municipalities of the State and in the urban area of Teresina and more than 12 species are recorded in the State (Martins et al. 1989, Vexenat et al. 1994).

\footnotetext{
This work was supported by CNPq, Fiocruz and Funasa. +Corresponding author. Fax: +55-31-3295.3566. E-mail: jandrade@cpqrr.fiocruz.br Received 19 October 2000 Accepted 23 August 2001
}

The aim of the present work is to identify the phlebotomine sand flies species in Piauí, as well as to provide some ecological data on the species of medical and veterinary interest.

Insects were captured from seven municipalities of Piauí: from 1997 to 1999 in Barro Duro, north of the State, they were captured inside the houses and in the peridomicile; in the municipalities of Picos and Floriano, in the central region of Piauí, captures were performed in 1998 inside the houses; in Picos, captures were also performed in na area of primary forest and in one cave; in Campo Maior, north of the State, and in Teresina, captures were done inside house during the year of 1998. In 1999 we performed captures in the municipality of São Raimundo Nonato, south of the State, in one cave. All captures were performed with CDC light trap between 5 and 8:00 AM.

After the captures the insects were fixed in alcohol $70^{\circ}$ mounted on glass slide using Berlese liquid. The identification was based on the classification of Young and Duncan (1994). Vouchers specimens are deposited in the collection of sand flies of the Centro de Pesquisas René RachouFiocruz (Nos. 2.363-72.769 and 76.192-76.641).

Seventeen species of sand flies were captured: Lutzomyia (Lutzomyia) longipalpis (Lutz \& Neiva 1912), Lutzomyia samueli (Deane 1955), Lutzomyia (Nyssomyia) whitmani (Antunes \& Coutinho 1939), Lutzomyia lenti (Mangabeira 1938), Lutzomyia (Lutzomyia) dispar Martins \& Silva 1963, 
Lutzomyia (Micropygomyia) oliveirai 1970 Martins, Silva \& Falcão, Lutzomyia goiana 1962 Martins, Falcão \& Silva, Lutzomyia (Sciopemyia) sordellii (Shannon \& Del Ponte 1927), Lutzomyia carmelinoi Ryan, Fraiha, Lainson \& Shaw 1986, Lutzomyia evandroi (Costa Lima \& Antunes 1936), Lutzomyia termitophila Martins, Falcão \& Silva 1964, Lutzomyia quinquefer (Dyar 1929), Lutzomyia peresi (Mangabeira 1942), Lutzomyia (Psathyromyia) sp., Lutzomyia (Micropygomyia) sp., Lutzomyia sp. and Brumptomyia avellari (Costa Lima 1932). Table shows the specimens captured in five municipalities of the State and also the ecotype where the species were caught compared with other authors.

L. longipalpis and L. lenti showed to be quite eclectic, being captured in all ecotypes. In the cave we collected nine species being $L$. samueli, L. lenti, L. dispar and Lutzomyia sp. more frequent. From the latter, we collected 14 males and 4 females which did not fit any of the known species and this material is reserved for posterior studies, as well as the other species that were identified up to subgenus level.

The genus Brumptomyia had not yet been reported for Piauí, as well as $L$. (N.) whitmani, $L$. (S.) sordellii, L. carmelinoi, L. termitophila, L. peresi and $L$. quinquefer. The first species is incriminated as a vector of cutaneous leishmaniasis in the South and Northeast regions of Brazil (Queiroz et al. 1994, Luz et al. 2000) and was frequent in the municipality of Barro Duro in the peridomicile, but a small number was captured inside the house, which suggests the beginning of domiciliarization of $L$. whitmani in Piauí, as observed by CampbellLendrum et al. (2000), species totally sylvatic in the North of Brazil (Lainson et al. 1979). Other species, $L$. (S.) sordellii, is synonym senior of Lutzomyia nordestina (Mangabeira 1942) (Young \& Morales 1987) and its geographical distribution comprises great part of the Brazilian territory (Martins et al. 1978).

L. carmelinoi and L. lenti are very close species but, up to now, $L$. carmelinoi was only reported in the North region of the country and $L$. lenti has extensive geographical distribution, being captured with frequency in chicken house and pigsty in other regions of Brazil (Gomes et al. 1978, Brazil et al. 1997). Despite being captured in a larger scale inside the houses, there is no evidence that this species is a vector of leishmaniasis in Brazil.

$L$. (L.) longipalpis has been captured frequently inside houses in the municipalities of Campo Maior and Floriano, with low numbers in the municipality

\section{TABLE}

Phlebotomine sand flies captured in the State of Piauí by us and by other authors and also the ecotype were the species were caught

\begin{tabular}{|c|c|c|c|c|c|}
\hline \multirow{3}{*}{ Species } & \multicolumn{5}{|c|}{ Authors } \\
\hline & \multirow[t]{2}{*}{ Martins et al. 1989} & \multirow{2}{*}{$\begin{array}{l}\text { Cipa Group } \\
\text { (on line) }\end{array}$} & \multicolumn{3}{|c|}{ This paper } \\
\hline & & & House & Cave & Forest \\
\hline Lutzomyia baityi & & $\mathrm{X}$ & & & \\
\hline Lutzomyia carmelinoi & & & $X$ & & \\
\hline Lutzomyia dispar & $\mathrm{X}$ & $\mathrm{X}$ & & $\mathrm{X}$ & \\
\hline Lutzomyia evandroi & $\mathrm{X}$ & $\mathrm{X}$ & & & \\
\hline Lutzomyia goiana & $X$ & $\mathrm{X}$ & $X$ & $X$ & \\
\hline Lutzomyia intermedia & & $\mathrm{X}$ & & & \\
\hline Lutzomyia lenti & $\mathrm{X}$ & $\mathrm{X}$ & $\mathrm{X}$ & $\mathrm{X}$ & $\mathrm{X}$ \\
\hline Lutzomyia longipalpis & $\mathrm{X}$ & $\mathrm{X}$ & $\mathrm{X}$ & $\mathrm{X}$ & $\mathrm{X}$ \\
\hline Lutzomyia oliveirai & $\mathrm{X}$ & $\mathrm{X}$ & & $\mathrm{X}$ & \\
\hline Lutzomyia oswaldoi & & $\mathrm{X}$ & & & \\
\hline Lutzomyia peresi & & & $\mathrm{X}$ & & $\mathrm{X}$ \\
\hline Lutzomyia quinquefer & & & $\mathrm{X}$ & & \\
\hline Lutzomyia samиeli & $\mathrm{X}$ & $\mathrm{X}$ & & $\mathrm{X}$ & $X$ \\
\hline Lutzomyia saulensis & & $\mathrm{X}$ & & & \\
\hline Lutzomyia shannoni & & $\mathrm{X}$ & & & \\
\hline Lutzomyia sordellii & & & $\mathrm{X}$ & & \\
\hline Lutzomyia termitophila & & & $\mathrm{X}$ & $\mathrm{X}$ & \\
\hline Lutzomyia walkeri & & $\mathrm{X}$ & & & \\
\hline Lutzomyia whitmani & & & $\mathrm{X}$ & & \\
\hline L. (Micropygomyia) sp. & & & & $\mathrm{X}$ & \\
\hline L. (Psathyromyia) sp. & & & $\mathrm{X}$ & & \\
\hline Lutzomyia sp. & & & & $\mathrm{X}$ & \\
\hline Brumptomyia avellari & & & $\mathrm{X}$ & & \\
\hline
\end{tabular}


of Picos independent of the capture site. According to Costa et al. (1990) this species is captured in large quantity in the urban area of Teresina.

The presence of Lutzomyia intermedia (Lutz \& Neiva 1912) in the State of Piauí was cited by other authors (Marcondes 1998). This is a sinantropic species, being caught with frequency in the Southeast region of Brazil (Lima 1986, Andrade Filho et al. 1997), although in Piauí we could not find $L$. intermedia, despite the large number of captures performed.

With these results the sand fly fauna in the State of Piauí is now composed by 20 species, being four (L. longipalpis, $L$. intermedia, $L$. shannoni e $L$. whitmani) suspect or confirmed vector of leishmaniasis in several regions of South America.

\section{REFERENCES}

Andrade Filho JD, Carneiro APS, Lima MLN, Santiago RM, Gama MA, Santos CA, Falcão AL, Brazil RP 1997. Flebotomíneos de Timóteo, estado de Minas Gerais, Brasil (Diptera: Psychodidae). Cad Saúde Públ 13: 767-770.

Brazil RP, Carneiro VL, Andrade Filho JD, Alves, JCM, Falcão AL 1997. Biology of Lutzomyia lenti (Mangabeira) (Diptera: Psychodidae). An Soc Entomol Brasil 26: 191-193.

Campbell-Lendrum DH, Brandão-Filho SP, Pinto MC, Vexenat A, Ready PD, Davies CR 2000. Domesticity of Lutzomyia whitmani (Diptera: Psychodidae) populations: field experiments indicate behavioural differences. Bull Entomol Res 90: 41-48.

Costa CHN, Pereira HF, Araújo MV 1990. Epidemia de leishmaniose no estado do Piauí, Brasil, 1980-1986. Rev Saúde Públ 24: 361-372.

Costa HC 1993. Urbanization of Kala-azar in Brazil. Kala-azar in Teresina, Piauí, Brazil. In Research and Control of Leishmaniasis in Brazil, Proceedings of a National Workshop, p. 109-124.

Gomes AC, Rabello EX, Galati EAB 1978. Flebotomíneos encontrados em galinheiros experimentais nos estados de São Paulo e Minas Gerais (Brasil) e algumas observações ecológicas. Rev Saúde Públ 12: 403-407.

Laison R, Shaw JJ, Ward RD, Ready PD, Naiff RD 1979. Leishmaniasis in Brazil: XIII. Isolation of Leishmania from armadillos (Dasypus novemcinctus) and ob- servations on the epidemiology of cutaneous leishmaniasis in North Pará State. Trans R Trop Med Hyg 73: 239-241.

Lima LC 1986. Ruralização de Lutzomyia intermedia, um provável caso de pré-adaptação. Rev Saúde Públ 20: 102-104.

Luz E, Membrive N, Castro EA, Dereure F, Pratlong J, Dedet A, Pandey A, Thomaz-Ssoccol 2000. Lutzomyia whitmani (Diptera: Psychodidae) as vector of Leishmania (V.) braziliensis in Paraná state, southern Brazil. Ann Trop Med Parasitol 94: 623631.

Marcondes CB, Lozovei AL, Vilela JH 1998. Distribuição geográfica de flebotomíneos do complexo Lutzomyia intermedia (Lutz \& Neiva, 1912) (Diptera, Psychodidae). Rev Soc Bras Med Trop 31: 51-58.

Martins AV, Dias ES, Falcão AL, Silva JE 1989. Notas sobre os flebótomos dos estados do Ceará e Piauí com a descrição da fêmea de Lutzomyia samueli (Deane, 1955) (Diptera, Psychhodidae: Phlebotominae). Mem Inst Oswaldo Cruz 84 (Supl. IV): 353-356.

Martins AV, Williams P, Falcão AL 1978. American Sand Flies (Diptera: Psychodidae: Phlebotominae), Acad Bras Ciências, Rio de Janeiro, 195pp.

Queiroz RG, Vaconcelos IAB, Vasconcelos AW, Pessoa FAC, Souza RN, David JR 1994. Cutaneous leishmaniasis in Ceará state in northeastern Brazil: incrimination of Lutzomyia whitmani (Diptera: Psychodidae) as a vector of Leishmania braziliensis in Baturite municipality. Am J Trop Med Hyg 50: 693698.

Vexenat JA, Fonseca de Castro JA, Cavalcante R, Tavares JP, da Silva MRB, Batista WH, Furtado Campos JH, Howard MK, Frame I, McNerney R, Wilson S, Miles MA 1994. Visceral leishmaniasis in Teresina, State of Piauí, Brazil: preliminary observations on the detection and transmissibility of canine and sandfly infections. Mem Inst Oswaldo Cruz 89: 131135.

Young DG, Duncan MA 1994. Guide to the identification and geographic distribution of Lutzomyia sand flies in Mexico, the west Indies, Central and South America (Diptera: Psychodidae). Mem Amer Ent Inst 54: $881 \mathrm{pp}$.

Young DG, Morales A 1987. New species and records of phlebotomine sand flies from Colombia (Diptera: Psychodidae). J Med Ent 24: 651-665. 
Phlebotomine in Piauí • José Dilermando Andrade Filho et al. 